\title{
Defense responses of wheat plants (Triticum aestivum L.) against brown spot as a result of possible elicitors application
}

\author{
Resposta de defesa das plantas de trigo (Triticum aestivum L.) \\ contra a mancha marrom diante da aplicação de possíveis elicitores
}

\author{
Elaine Pittner ${ }^{1 *}$ (D), Janaina Marek' ${ }^{1}$ (D), Douglas Bortuli' ${ }^{1}$ (D), \\ Leandro Alvarenga Santos ${ }^{1}$ (D), Adriana Knob ${ }^{1}$ (D), Cacilda Marcia Duarte Rios Faria' (D)
}

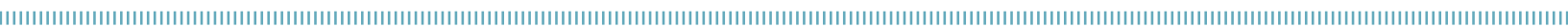

\begin{abstract}
The objective of this research was to evaluate the response of wheat plants to the application of possible elicitor compounds against Bipolaris sorokiniana pathogen. This response was measured through the quantification of antioxidant enzymes, malondialdehyde and flavonoids, evaluation of the severity of brown spot disease and productivity in wheat, greenhouse and field crops. The treatments consisted of suspensions of endophytic fungi Aspergillus japonicus and Trichoderma tomentosum, salicylic acid, acibenzolar-S-methyl and fungicide. In the field trials, in 2015 and 2016, the development of the disease was lower and productivity was higher in all treatments, with emphasis on the fungicide. However, endophytic fungi suspensions demonstrated potential as growth promoters, disease severity reducers and protective antioxidant response activators, as they promoted significant increase in superoxide dismutase, catalase, glutathione and flavonoid enzymes.
\end{abstract}

KEYWORDS: Bipolaris sorokiniana; catalase; ascorbate; glutathione; flavonoids.
RESUMO: O objetivo desta pesquisa foi avaliar a resposta de plantas de trigo diante da aplicação de possíveis compostos elicitores perante o patógeno Bipolaris sorokiniana. Tal resposta foi examinada por meio da quantificação de enzimas antioxidantes, malondialdeído e flavonoides, da análise da severidade da doença mancha marrom e da produtividade na cultura do trigo, em casa de vegetação e em campo. Os tratamentos consistiram em suspensóes de fungos endofíticos Aspergillus japonicus e Trichoderma tomentosum, ácido salicílico, acibenzolar-S-metil e fungicida. Nos ensaios em campo, em 2015 e 2016, o desenvolvimento da doença foi menor e a produtividade foi superior em todos os tratamentos, com destaque para o fungicida. No entanto, as suspensões de fungos endofíticos demonstraram potencial como promotores de crescimento, redutores da severidade da doença e ativadores de resposta antioxidante protetora, pois promoveram o aumento significativo das enzimas superóxido dismutase e catalase, das glutationas e flavonoides.

PALAVRAS-CHAVE: Bipolaris sorokiniana; catalase; ascorbato; glutationa; flavonoides. 


\section{INTRODUCTION}

Wheat consumption in Brazil exceeds 10 million tons/year. Due to the high demand observed, domestic production of this grain is not sufficient to supply the domestic market. Therefore, there is the need to import part of the wheat consumed (EMBRAPA, 2004). This lower production than the market demand is due to several factors, such as the reduction of cultivated areas and the climate with hot and humid winters, which favor the development of fungal diseases (IFTIKHAR et al., 2012).

Among the pathogens that infect this culture can be cited Bipolaris sorokiniana (Sacc. em Sorok) (Shoemaker, 1959) teleomorfa: Cochliobolus sativus (Ito \& Kuribayashi) Drechsl ex Dastur - , a phytopathogenic fungus found worldwide that causes diseases in wheat and other winter cereals. The disease caused by this fungus receives several names, such as: brown spot, common root rot and black spot of the grain (DUVEILLER et al., 2002). Due to the great morphological, physiological and genetic variability of this pathogen, the adoption of adequate measures for control becomes difficult.

In recent years, several studies have been conducted to find elicitor compounds that are capable of promoting the activation of plant defense mechanisms for the control of pathogens of commercial importance, such as B. sorokiniana. Some researches show that the application of suspensions of fungi of genus Trichoderma diminishes the severity of brown spot caused by $B$. sorokiniana in wheat, a fact that is due to the activation of the plant defense mechanisms, improvement of the productivity and plant development (HASAN et al., 2012; HASAN, 2013; HOSSAIN et al., 2016).

It is known that, from the interaction between plant and pathogen, receptors on the surface of plants recognize elicitor proteins produced by the pathogen, triggering a signaling to the nucleus of the cells. This, in turn, triggers the process of producing different enzymes and compounds in the search for the plant protection. At this time, the production of reactive oxygen species (ROS) occurs simultaneously. Frequently, plants respond to hemibiotrophic pathogens, such as B. sorokiniana, with activation of the route of salicylic acid (SA) (THAKUR; SOHAL, 2013). Faced with the application of elicitor compounds (biotic or abiotic), these mechanisms are pre-activated, potentiating and accelerating plant defense (ZHANG et al., 2010; GAO et al., 2015; OLIVEIRA et al., 2016).

Among the enzymes that are formed to control the excess of reactive oxygen species (EROs), catalase (CAT, EC 1.11.1.6), superoxide dismutase (SOD, EC 1.15.1.1), ascorbate peroxidase (APX, EC 1.11.1.1), glutathione reductase (GR, EC 1.6.4.2), glutathione S-transferases (GST, EC 2.5.1.18) and glutathione peroxidase (GPX, EC 1.11.1.9) (KIM; KWAK, 2010) can be cited. These enzymes have antioxidant action and can prevent the formation of free radicals, sequester them or even degrade them, thus preventing or minimizing damage to plant cells (SERKEDJIEVA, 2011). These mechanisms, in addition to preventing the effects of ROS, may also decrease extreme oxidative stress (BHATTACHARJEE, 2010; SERKEDJIEVA, 2011; VARGA et al., 2012; MISHRA et al., 2013; RAO et al., 2013; HUSEYNOVA et al., 2014; KONG et al., 2013; TALAAT; SHAWKY, 2014; NOCTOR et al., 2015).

In this sense, several agents have been investigated as possible elicitors of plant defense responses or resistance inducers. Among the abiotic elicitors, SA, some fungicides and acibenzolar-S-methyl (ASM) can be mentioned. When applied exogenously, SA improves productivity, growth, photosynthesis, water relations of plants and various enzymatic activities. In addition, its effect on the defense responses of plants exposed to various biotic and abiotic stresses has also been verified (HAYAT et al., 2010; GAO et al., 2015). SORAHINOBAR et al. (2016) observed that, when applying SA in wheat, it was able to induce resistance to the pathogen Fusarium graminearum, decreasing the disease severity and increasing the activity of enzymes such as peroxidase (POD) and SOD. ASM elicits defense responses in a variety of plant species against various pathogens (fungi, bacteria and viruses) and in some nematodes and insects (INBAR et al., 2001).

Among the biotic elicitor factors, endophytic fungi, including species of the genus Trichoderma and Aspergillus, can act directly in the confrontation with pathogens, disputing space or food, or indirectly, through the production of compounds or induction of resistance in plants (BAE et al., 2011; ZHAO et al., 2011; KHAN et al., 2013; DUTTA et al., 2014; HOSSEYNI-MOGHADDAM; SOLTANI, 2014).

In view of these considerations, the objective of this research was to measure the response of wheat plants to the application of possible elicitor compounds against the $B$. sorokiniana pathogen, through the quantification of antioxidant enzymes, malondialdehyde (MDA) and flavonoids, evaluation of disease severity brown spot and crop productivity, in greenhouse and field.

\section{MATERIALS AND METHODS}

\section{In vitro assays}

The isolation of endophytic fungi from weeds was performed according to PEREIRA et al. (1993) and ARAÚJO et al. (2002) at the Laboratory of Plant Pathology, Cedeteg Campus, Universidade Estadual do Centro-Oeste (UNICENTRO), Guarapuava, PR, Brazil. Weed samples (Brachiaria plantaginea, Rumex obtusifolius L., Sida rhombifolia L., Euphorbia heterophylla L.) were collected at the Cedeteg Campus, located at latitude $25^{\circ} 23^{\prime} 06^{\prime \prime}$ South and longitude 51 $29^{\prime} 46^{\prime \prime}$ West, with altitude of $1,027 \mathrm{~m}$. 


\section{Obtaining suspensions of endophytic fungi}

To obtain the suspensions, the endophytic fungi were cultivated in petri dishes containing potato dextrose agar (PDA) at $28^{\circ} \mathrm{C}$. After seven days of culture, $9 \mathrm{~mm}$ disks from the colonies were transferred to $250 \mathrm{~mL}$ Erlenmeyers containing $150 \mathrm{~mL}$ of liquid PDA medium (20\% potato, $2 \%$ dextrose). The fungi were grown for seven days under constant stirring at $150 \mathrm{rpm}$ at $28^{\circ} \mathrm{C}$. After this period, the spore count was adjusted and the inoculum adjusted to $1 \times 108$ conidia/mL (PERELLÓ et al., 2008).

\section{Greenhouse}

The experiment was conducted in a greenhouse at Cedeteg Campus. Seeds of the BRS Sabiá cultivar were seeded in $11 \mathrm{~L}$ pots with soil and Plantmax ${ }^{\odot}$ substrate (v:v). The fertilization of sowing was according to the interpretation of soil chemical analysis, by the Manual of Fertilization and Liming for the State of Paraná (IAPAR, 2003), and the dose calculated in relation to the volume of each pot $(11 \mathrm{~L})$.

The experimental design involved a randomized block design (RBD) in the field and a completely randomized block design (CRBD) in the greenhouse, with or without treatments, both with five replications, with four plants in each vase considered a repetition. The following treatments were applied to each plant:

- $\quad \mathrm{T} 1$ = suspension of endophytic fungi Aspergillus japonicus;

- $\mathrm{T} 2$ = suspension of endophytic fungi Trichoderma tomentosum;

- $\quad \mathrm{T} 3=$ SA $0.7 \mathrm{mM}$;

- $\mathrm{T} 4$ = ASM $300 \mathrm{mg} / \mathrm{L}$;

- $\mathrm{T} 5$ = fungicide (Azoxystrobin $120 \mathrm{~g} / \mathrm{L}+$ Tebuconazole $200 \mathrm{~g} / \mathrm{L})$;

- $\quad$ T6 = sterilized distilled water application with B. sorokiniana inoculum;

- $\quad \mathrm{T} 7$ = without any application.

\section{Area under the disease progress curve}

The evaluation of severity was according to the diagrammatic scale of JAMES (1971), and carried out every five days, in three leaves of each marked plant, totalizing 10 evaluations. The area under the disease progress curve (AUDPC) was determined by the following formula, expressed in Equation 1:

$\mathrm{AUDPC}=\Sigma[(\mathrm{Si}+\mathrm{Si}+1) / 2 .(\mathrm{Ti}+1-\mathrm{Ti})] \mathrm{Q}$

In which:

$\mathrm{Si}=$ severity of the disease at time of evaluation $\mathrm{i}$;

$\mathrm{Ti}=$ plant age at time of evaluation i (CAMPBELL; MADDEN, 1990).

\section{Biochemical analysis}

Biochemical analyses were performed on leaves of wheat plants grown in greenhouse. For the biochemical analyses in leaf tissues, leaf samples were collected at the following times 48, 72, 96, 120 and $144 \mathrm{~h}$ after inoculation of the B. sorokiniana pathogen, which occurred in 52 days after inoculation (DAI). Immediately after the leaves were collected, they were frozen in liquid nitrogen and stored in a freezer at $-20^{\circ} \mathrm{C}$ until the time of evaluation.

\section{Protein extraction}

Protein extraction was conducted according to Moerschbacher (1988), described by GUZZO; MARTINS (1996); and quantification of total protein content in the samples was performed according to BRADFORD (1976).

Quantification of SOD (EC 1.15.1.1) was determined by the spectrophotometric method described by GIANNOPOLITIS; RIES (1977), the reading being carried out in a spectrophotometer at $560 \mathrm{~nm}$ and the results expressed in $\mathrm{U} S O D \mathrm{mg}^{-1}$ total protein.

Measurement of CAT (EC 1.11.1.6) was determined by the method described by FERREIRA et al. (2006), with a spectrophotometer reading at $240 \mathrm{~nm}$. The results were expressed

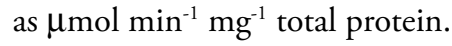

The determination of GR (EC 1.6.4.2) was measured according to FERREIRA et al. (2006), with spectrophotometer reading at $412 \mathrm{~nm}$. Activity values were expressed as $\mu \mathrm{mol}$ $\mathrm{min}^{-1} \mathrm{mg}^{-1}$ total protein.

The activity of GST (EC 2.5.1.18) was measured according to CATANEO et al. (2003), with spectrophotometer reading at $340 \mathrm{~nm}$. The specific reaction rate was given by the variation in absorption using the molar extinction coefficient of $9.6 \mathrm{mM}^{-1} \mathrm{~cm}^{-1}$. The amount of enzyme producing $1 \mu \mathrm{mol} \mathrm{min} \mathrm{m}^{-1}$ is defined as a GST unit.

The activity of APX (EC 1.11.1.11) was quantified according to NAKANO; ASADA (1981), described by FLORES et al. (2014), and the enzymatic activity was calculated using the molar extinction coefficient of $2.8 \mathrm{mM} \cdot \mathrm{cm}^{-1}$. One unit of activity $(\mathrm{U})$ was defined as the amount of enzyme required to convert $1 \mathrm{nmol}$ of substrate into product per minute per $\mathrm{mL}$ under the assay conditions.

The determination of lipoxigenase (LOX) (EC 1.13.11.12) was performed according to the method described by AXELROD et al. (1981). The reaction rate was determined every $30 \mathrm{sec}-$ onds at $234 \mathrm{~nm}$ for a period of 120 seconds.

The POD activity of GPX (EC 1.11.1.9) was measured according to NAGALAKSHMI; PRASAD (2001). The enzymatic activity was calculated using the molar extinction coefficient of 6.22 $\mathrm{mM}^{-1} \mathrm{~cm}^{-1}$ and the result expressed in $\mathrm{mmol} \mathrm{min}{ }^{-1} \mathrm{mg}^{-1}$ protein.

\section{Malondialdehyde concentration}

The lipid peroxidation was inferred by determination of the MDA content, secondary product of the peroxidation process, according to 
the BUEGE; AUST (1978) method, with modifications. For extraction of MDA, $250 \mathrm{mg}$ of leaf samples were macerated in liquid nitrogen until a homogeneous powder was formed, adding $10 \%$ of polyvinylpolypyrrolidone (PVPP). Thereafter, $2 \mathrm{~mL}$ of $0.1 \%(\mathrm{w} / \mathrm{v})$ trichloroacetic acid (TCA) was added. After homogenization, the extract was centrifuged at $10,000 \mathrm{~g}$ at $25^{\circ} \mathrm{C}$ for $5 \mathrm{~min}$. To a 250 $\mu \mathrm{L}$ volume of the supernatant, $1 \mathrm{~mL}$ of solution containing $20 \%$ $(\mathrm{w} / \mathrm{v})$ TCA and $0.5 \%(\mathrm{w} / \mathrm{v})$ thiobarbituric acid (TBA) was added. Samples were held for $30 \mathrm{~min}$ at $95^{\circ} \mathrm{C}$ and then transferred to ice bath for $10 \mathrm{~min}$. After cooling, the samples were centrifuged at $10,000 \mathrm{~g}$ at $25^{\circ} \mathrm{C}$ for $10 \mathrm{~min}$, in order to separate any solid residue formed during heating in the samples. The readings were performed in a spectrophotometer at 535 and $600 \mathrm{~nm}$. Determination of the equivalent of the MDA concentration was calculated using the molar extinction coefficient of $155 \mathrm{mM}^{-1} \mathrm{~cm}^{-1}$. The results were expressed as $\mu \mathrm{mol} \mathrm{kg}^{-1}$ fresh weight (FW).

\section{Determination of total flavonoid concentrations}

The flavonoid content of wheat leaves was determined using the colorimetric method of aluminum chloride of CHANG et al. (2002). Dilution of wheat leaf extracts was done according to MOORE et al. (2006), with $0.5 \mathrm{~mL}$ being mixed with $1.5 \mathrm{~mL}$ of $95 \%$ ethanol followed by $0.1 \mathrm{~mL}$ of $10 \%$ aluminum chloride, $0.1 \mathrm{~mL}$ of $1 \mathrm{M}$ potassium acetate and $2.8 \mathrm{~mL}$ of water distilled water. After incubation at room temperature for $30 \mathrm{~min}$, the absorbance of the mixture was evaluated at $415 \mathrm{~nm}$. The values were expressed as $\mu \mathrm{g} \mathrm{g}^{-1}$ dry weight (DW).

\section{Inoculum of Bipolaris sorokiniana}

The B. sorokiniana isolate was obtained from the Universidade Tecnológica Federal do Paraná and multiplied in PDA medium, being incubated in a biochemical oxygen demand (BOD) for 15 days at $25^{\circ} \mathrm{C}$, in 12 hours of photoperiod. After this incubation in petri dishes, the pathogen inoculum was standardized as follows: the colonies were lightly scraped with Drigalski loop and the inocula were transferred to sterile glass test tubes containing $5 \mathrm{~mL}$ of sterile saline $(0.85 \%)$ with Tween $80(0.1 \%)$. Then the final conidia concentration was adjusted to 106 spores $/ \mathrm{mL}^{-1}$ in Neubauer's chamber (MINOTTO et al., 2014). For inoculation of the pathogen, $5 \mathrm{~mL}$ of the adjusted conidia suspension was sprayed per plant, and the vessels were then kept in a humid chamber for 48 hours.

Field experiments were carried out in 2015 and 2016 in an experimental area of the Phytopathology Department of the Agronomy Department of UNICENTRO, Cedeteg Campus, Guarapuava, Paraná, Brazil, at latitude $25^{\circ} 23^{\prime} 06^{\prime \prime}$ South and longitude $51^{\circ} 29^{\prime} 46^{\prime \prime}$ West, with altitude of $1,027 \mathrm{~m}$. The wheat cultivar used was BRS Sabiá.

The local climate is classified as humid subtropical $\mathrm{Cfb}$, by Köppen classification, with hot summers, winters with frequent frost occurrence, annual mean temperature of $17^{\circ} \mathrm{C}$ and annual average rainfall of 1,946 $\mathrm{mm}$ (WREGE et al., 2011). The local soil is classified as typical dystroferric Bruno Latosol, according to Empresa Brasileira de Pesquisa Agropecuária (EMBRAPA, 2013) classification, with a very clayey texture resulting from a lava spill known as Trapp.

\section{Evaluation of the height and productivity of wheat plants}

The height measurement of the wheat plants was performed above the soil, sampling 10 plants from the central rows. In order to evaluate the productivity of wheat plants, the mean value obtained by counting the number of ears in a sample of one linear meter in the useful area of the plot was taken into account, as well as the average value obtained by counting the number of grains in a sample of ten ears collected in the plot area. To determine the grain productivity of each experiment, after harvesting and drying, the grains of the plots were weighed on a precision scale, and the productivity was expressed in $\mathrm{kg} \mathrm{ha}^{-1}$, with correction for 13\% moisture (KRUPA E SILVA, 2014).

\section{RESULTS AND DISCUSSION}

Regarding productivity (Table 1), it was observed that the best results were for the treatment with fungicide (T5), in 2015 and 2016, presenting approximately $18 \%$ higher yields than the control (T6). However, it is noted that treatments 1 and 2, with the suspensions of $A$. japonicus and T. tomentosum, respectively, showed potential as growth promoters, once the yield was higher than the control values. Thus, the use of these fungi, especially T. tomentosum, can contribute to crop productivity, since the application of fungi of the genus Trichoderma sp. are able to promote plant growth and inhibit pathogen growth by minimizing the effects of diseases on wheat plants (HASAN et al., 2012). Also, due to the inhibition of leaf spot, a larger green leaf area is obtained, providing higher rate of photosynthesis, which allows an increase of production.

Regarding the indices of development of the plants, number of spikes, number of grains per spike and height of plants, all the treatments reached higher evaluations than the control ones. This data set evidences the potential of using the application of suspensions of endophytic fungi, as well as the application of SA via foliar to improve the development of wheat plants and contribute to their productivity. It is known that fungi of the genus Trichoderma have the capacity to minimize the effects of fungal diseases, providing increase in productivity (WAGHUNDE et al., 2016).

Endophytic fungi can grow faster or use their food source more efficiently than the pathogen, thus preventing the pathogen from settling down. Furthermore, they can excrete compounds that inhibit the growth of pathogens in the neighboring area by antibiosis or directly feed on a pathogenic species, which is known as parasitism (ZHAO et al., 2011; KHAN et al., 2013; GAJERA 
et al., 2013; DUTTA et al., 2014). In this way, the endophytic fungi interfere in the proliferation of phytopathogens and, consequently, contribute to the development of the plant.

In relation to the severity in the field area in the Cedeteg Campus (Fig. 1), in 2015 and 2016, it was possible to verify that all treatments with biotic and abiotic elicitors were efficient in controlling the disease, when compared to the control (T6), presenting significant differences. In addition to the fungicide, the treatments that showed lower values of AUDPC were ASM and SA, which also differed significantly from treatments with fungal suspensions. Treatment 7, which consisted in the absence of inoculation of the pathogen and the non-application of any type of treatment, presented small AUDPC, which can prove natural infection of the pathogen in the area. The applied elicitors appear to be involved in the production of enzymes and other compounds that activate the resistance in wheat plants. ANTONIAZZI; DESCHAMPS (2007), after applying the xanthan and allicin elicitors, observed improvement in wheat yield, which reduced the brown spot severity in a manner equivalent to the fungicide.

Endophytic fungi suspensions were also able to promote reduction in disease severity when compared to the control,

Table 1. Plant height and productivity of wheat cultivar BRS Sabiá, Campus Cedeteg, Universidade Estadual do CentroOeste, Guarapuava, PR, Brazil.

\begin{tabular}{|c|c|c|c|c|}
\hline Treatments & $\begin{array}{c}\text { Yield } \\
\text { kg ha-1 }^{-1}\end{array}$ & $\begin{array}{l}\text { Number of } \\
\text { cobs } \mathrm{m}^{-2}\end{array}$ & $\begin{array}{l}\text { Number } \\
\text { of grains }{ }^{-1}\end{array}$ & $\begin{array}{l}\text { Height of } \\
\text { plants }(\mathrm{cm})\end{array}$ \\
\hline \multicolumn{5}{|c|}{ Crop 2015} \\
\hline $\mathrm{T} 1$ & 2877.4 e & 348.8 a & $25.0 \mathrm{c}$ & $87.8 \mathrm{c}$ \\
\hline $\mathrm{T} 2$ & 2949.4 d & 349.2 a & $25.6 b$ & $88.2 \mathrm{c}$ \\
\hline T3 & $3051.2 c$ & $350.6 \mathrm{a}$ & $25.6 b$ & $89.0 \mathrm{~b}$ \\
\hline T4 & $3133.8 b$ & $349.8 \mathrm{a}$ & $25.6 b$ & $88.9 b$ \\
\hline T5 & 3399.8 a & 349.8 a & $27.0 \mathrm{a}$ & 89.7 a \\
\hline T6 & $2464.6 \mathrm{~g}$ & $339.8 b$ & $23.4 \mathrm{~d}$ & $85.2 \mathrm{e}$ \\
\hline T7 & $2796.8 \mathrm{f}$ & 349.6 a & $25.0 \mathrm{c}$ & $86.9 d$ \\
\hline CV (\%) & 1.72 & 0.32 & 1.64 & 0.42 \\
\hline \multicolumn{5}{|c|}{ Crop 2016} \\
\hline T1 & $2893.6 \mathrm{~d}$ & $346.0 \mathrm{~b}$ & $24.6 \mathrm{bc}$ & 89.5 bc \\
\hline T2 & $2921.4 d$ & $346.8 a b$ & $24.6 \mathrm{bc}$ & $89.9 c$ \\
\hline T3 & 3005.2 bc & $347.4 \mathrm{ab}$ & $25.6 a b$ & $90.7 a b$ \\
\hline T4 & $3046.2 \mathrm{ab}$ & 350.0 a & $25.8 \mathrm{a}$ & $90.7 \mathrm{ab}$ \\
\hline T5 & $3184.4 \mathrm{a}$ & $350.0 \mathrm{a}$ & $26.0 \mathrm{a}$ & $91.5 \mathrm{a}$ \\
\hline T6 & $2592.4 \mathrm{e}$ & $340.0 \mathrm{c}$ & $23.4 \mathrm{~d}$ & 86.9 e \\
\hline T7 & $2768.6 d$ & $349.6 \mathrm{a}$ & $24.0 \mathrm{~cd}$ & $88.7 d$ \\
\hline CV (\%) & 6.71 & 1.05 & 4.15 & 1.67 \\
\hline
\end{tabular}

Averages followed by the same letter in the column do not differ statistically from each other by the Scott-Knott test at the 5\% probability level; T1: suspension of Aspergillus japonicas; T2: suspension of Trichoderma tomentosum; T3: salicylic acid; T4: acibenzolar-s-methyl; T5: fungicide (Azoxystrobin with Tebuconazole); T6: application of distilled water sterilized and with inoculum of Bipolaris sorokiniana; T7: without any application; CV: coefficient of variation. especially in relation to the application of T. tomentosum. Similarly, PERELLÓ et al. (2003) found that the application of Trichoderma sp. significantly reduced the severity of rust disease in wheat plants compared to untreated plants.

Among the biotic elicitors, the ability of fungi such as those of the Trichoderma genus to activate defense responses in plants has also been known. In addition to the antagonistic effect of these fungi on phytopathogens, their potential in plant growth and development, as well as the induction of resistance to a wide variety of pathogens, have been reported and considered relevant (PERELLÓ et al., 2008; BAE et al., 2011; HASAN et al., 2012; YOSHIOKA et al., 2012; MISHRA et al., 2013; CARVALHO et al., 2015; HASSANEIN et al., 2016; WAGHUNDE et al., 2016). YOSHIOKA et al. (2012) affirm that endophytic fungi, including Trichoderma species, are capable of producing self-protection and plant protection compounds. Moreover, fungi of the genus Aspergillus are also capable of producing substances with an antagonistic effect on certain pathogens (GUNATILAKA, 2006; KUSARI et al., 2009).

The most common disease control in triticulture is the application of fungicides. However, this control method, besides being able to cause environmental contamination, has been restricted due to the emergence of resistant isolates of the pathogen. As an alternative to chemical control, the use of biological products and resistance inducers has become increasingly frequent.

PERELLÓ et al. (2006) evaluated the effect of Trichoderma harzianum and T. koningii on pathogens Pyrenophora tritici-repentis and Mycosphaerella graminicola in wheat under field conditions.

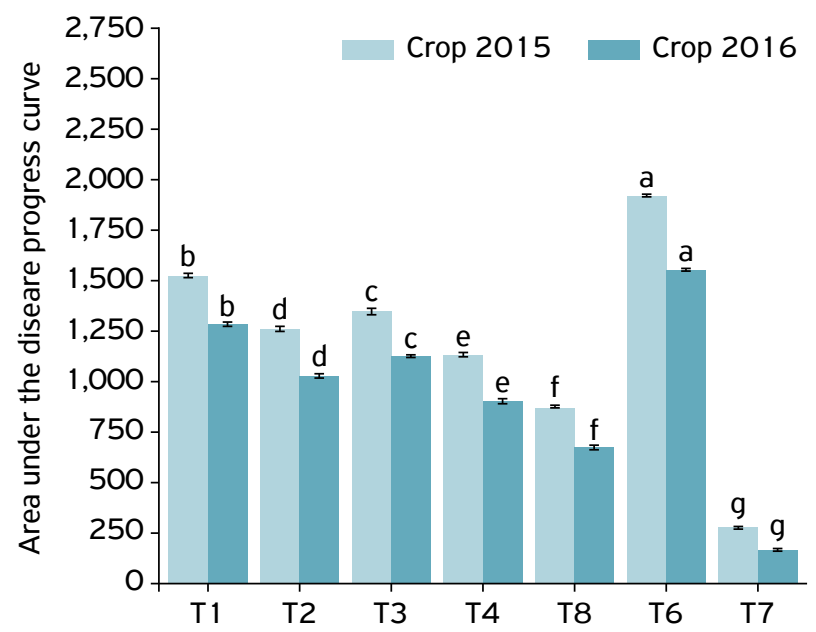

Averages followed by distinct letters between treatments differ by the Scott-Knott test at the $5 \%$ probability level; bars indicate standard average deviation; T1: suspension of Aspergillus japonicas; T2: suspension of Trichoderma tomentosum; T3: salicylic acid; T4: acibenzolar-s-methyl; T5: fungicide (Azoxystrobin with Tebuconazole); T6: application of sterilized distilled water and with inoculum of Bipolaris sorokiniana; $\mathrm{T} 7$ : without any application.

Figure 1. Area under the disease progression curve of the brown spot in the cultivar BRS Sabiá, field in Cedeteg Campus, Universidade Estadual do Centro-Oeste, Guarapuava, PR, Brazil. 
There was decrease in the severity of the diseases when compared to the control, and some evaluations obtained in relation to the fungal treatments were similar to Tebuconazole.

CORDO et al. (2007), in greenhouse work, evaluated two methods of application of Trichoderma spp. in wheat, in seeds and foliar application. In both methods, the authors verified that the Trichoderma isolates stimulated induced systemic response in wheat plants, protecting the plants from the leaf spot caused by the pathogen Septoria tritici.
In relation to the enzymes evaluated, the CAT enzyme (Fig. 2A) had its activity increased by approximately three times as a result of ASM application at 72 and 96 hours after inoculation (HAI). By using the suspensions of endophytic fungi, we obtained more expressive results in 120 HAI. In addition, plants that were inoculated with pathogen but were witnesses had higher activity than all treatments in the HAI time. Supposedly, this increase of the activity of the later CAT enzyme in the control plants is due to the natural defense

A

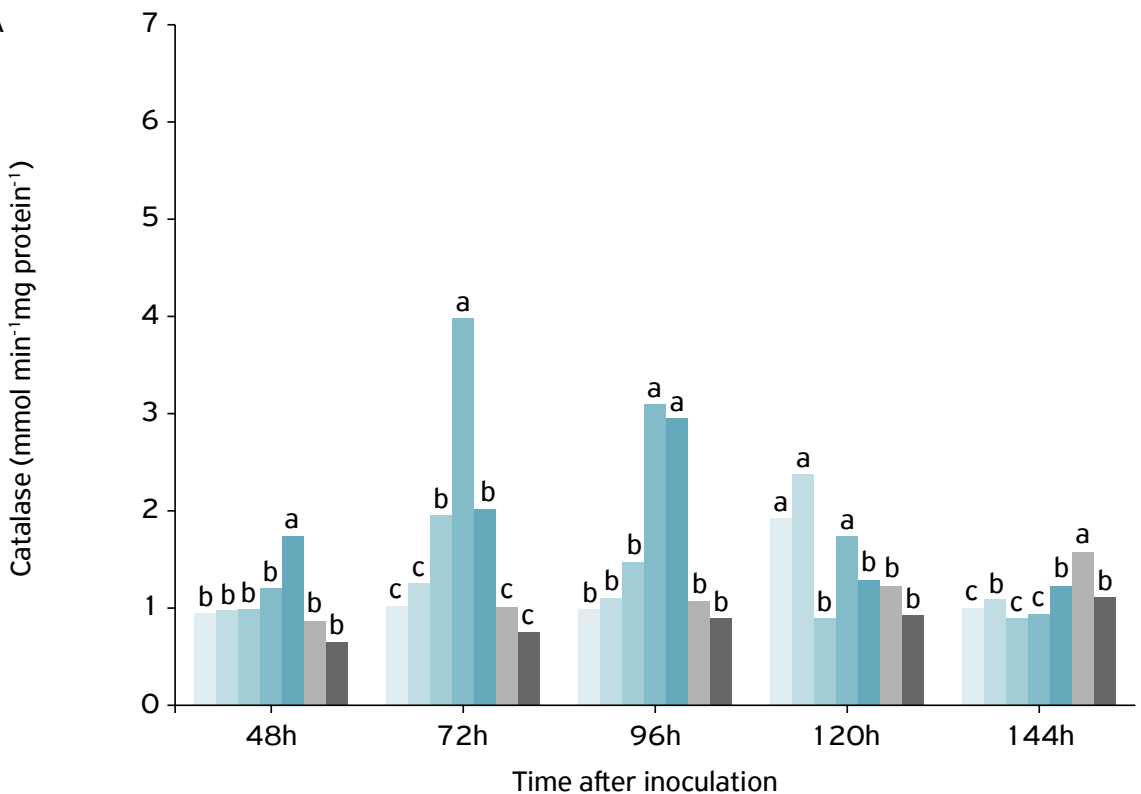

B

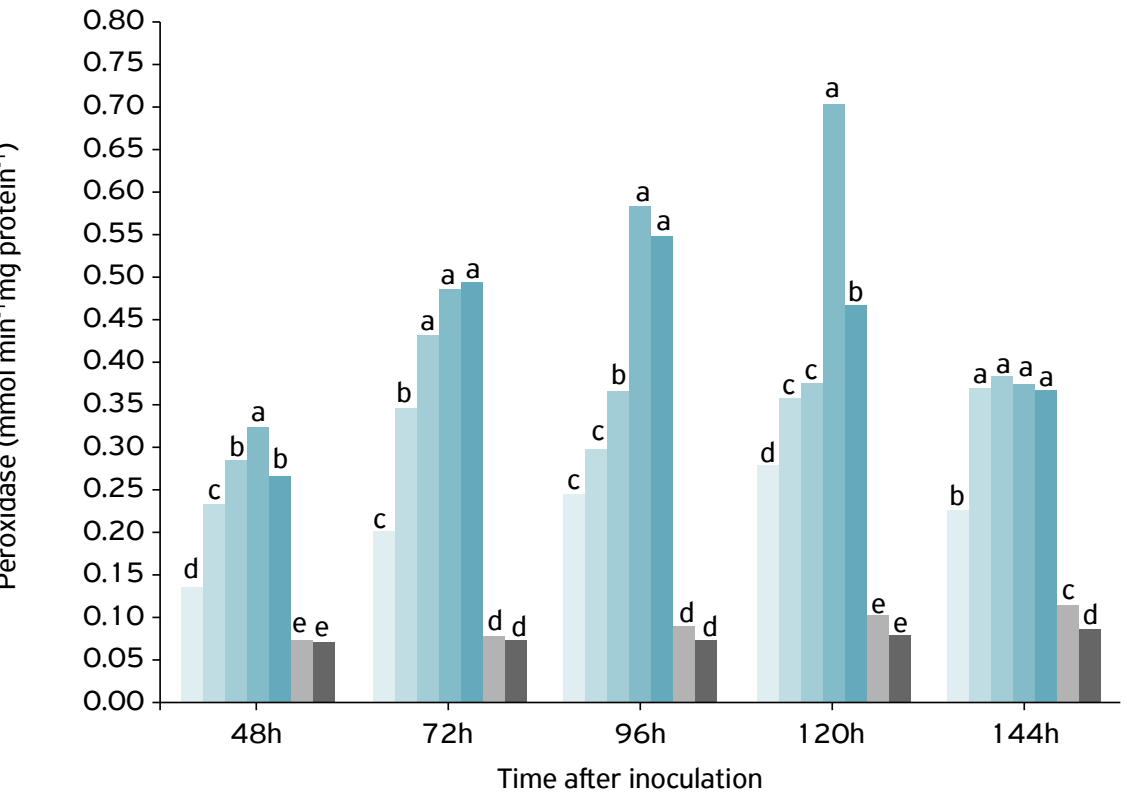

T1

T2

T3

T4

Averages followed by distinct letters between treatments differ by the Scott-Knott test at the 5\% probability level; T1: suspension of Aspergillus japonicas; T2: suspension of Trichoderma tomentosum; T3: salicylic acid; T4: acibenzolar-s-methyl; T5: fungicide (Azoxystrobin with Tebuconazole); T6: application of sterile distilled water with inoculum of Bipolaris sorokiniana; T7: without any application.

Figure 2. Activity of the enzymes (A) catalase and (B) peroxidase, after inoculation of the Bipolaris sorokiniana pathogen. 
response of the plant. However, it is evident that plants treated with different elicitors have their defenses preactivated, that is, the defense responses are anticipated, so the plants can defend themselves more effectively against the attack of the disease.

The POD enzyme (Fig. 2B) presented a seven-fold increase in its ASM activity at $120 \mathrm{HAI}$, when compared to the control. The treatments with the suspensions of endophytic fungi, especially the suspension with fungus T. tomentosum, were also superior to the control, in most of the times analyzed.

The enzyme CAT is responsible for the direct dissociation of $\mathrm{H}_{2} \mathrm{O}_{2}$ in $\mathrm{H}_{2} \mathrm{O}$ and $\mathrm{O}_{2}$, removing this peroxide generated in the peroxisomes by oxidases involved in the oxidation of fatty acids, photorespiration and purine catabolism (AHMAD et al., 2010). High levels of $\mathrm{H}_{2} \mathrm{O}_{2}$ are toxic to the plant, while the lower concentrations play a very important role in signal transduction in the attacked plants (SCANDALIOS et al., 2000).

It was observed in our results with application of $S A$ that the CAT activity was lower when compared with ASM and fungicide. This is probably due to the fact that AS inhibits the expression of genes encoding CAT, although it is correlated with the activation of defense-related genes and other enzymes, such as POD (HORVÁTH et al., 2002). In our results, when SA was applied, the POD activity was equal to that obtained by treatment with fungicide at 48, 72 and 144 hours.

After infection of the plant by pathogens, an increase of $\mathrm{H}_{2} \mathrm{O}_{2}$ is observed, which, in excess, can harm the cell. However, under the action of CAT, it is converted to $\mathrm{O}_{2}$ and $\mathrm{H}_{2} \mathrm{O}$ (DEBONA et al., 2012). Although strobilurins and triazoles are widely recognized for their fungicidal effect, they may also affect the plant's antioxidant system (WU; VONTIEDEMANN, 2001; ZHANG et al., 2010), thus favoring the removal of ROS. Similarly, SA, ASM and biological agents with special emphasis on the fungus Trichoderma sp. can activate enzymes in plants, favoring their protection against pathogens (GHOLAMNEZHAD et al., 2016; RIOS et al., 2014).

When evaluating the enzymes that fight ROS in two wheat cultivars, DEBONA et al. (2012) verified that, after infection with Pyricularia oryzae, concentrations of $\mathrm{O}_{2}, \mathrm{H}_{2} \mathrm{O}_{2}$ and MDA were increased. Furthermore, after inoculation of the pathogen, the authors observed that the SOD, POD, APX and GST activity increased for both cultivars when compared to the non-inoculated plants, with the increases being more pronounced after 96 hours, whereas the activity of GPX increased in inoculated plants after 48 and 72 hours.

According to Figure 3A, both the SOD enzyme and the LOX (B) enzyme showed the greatest increase in HAI time 120 with ASM treatment. According to THAKUR; SOHAL (2013), many compounds have been commercially released in some countries as an annual crop plant promoter, such as compound ASM. This compound is AS-dependent defense pathway and activates acquired systemic resistance (ASR).

LOX is an isoenzyme that catalyzes the addition of molecular oxygen to the pentadiene system of polyunsaturated fatty acids and is involved in the initial degradation of lipids to form products in response to injury, such as calluses and in the biosynthesis of regulatory compounds such as jasmonic acid, which acts on resistance to pathogens and aldehydes with antifungal action (OLIW, 2002). SOD converts the superoxide anion to hydrogen peroxide and can be bound to a metal ( $\mathrm{Cu} / \mathrm{Zn}, \mathrm{Mn}$ and $\mathrm{Fe})$. Plants usually have $\mathrm{Cu} / \mathrm{Zn}-\mathrm{SOD}$ in the cytosol, $\mathrm{Cu} / \mathrm{Zn}$ and/or Fe-SOD in the chloroplast and Mn-SOD in the mitochondria (RESENDE et al., 2003; GILL et al., 2015).

It is noticed that some fungicides have the capacity to activate the antioxidant mechanism in wheat plants. ZHANG et al. (2010) observed that the fungicide JS399-19 (Azoxystrobin + Tebuconazol) when applied in different wheat cultivars promoted a delay in senescence and improved the protective activity, with higher production of antioxidant enzymes. In addition, when applied to the fungicide, higher productivity was observed when compared to other treatments. Studies have reported that the fungicides strobilurins, triazoles and benzimidazoles, although having different mode of action, present antioxidant properties in wheat (WU; TIEDEMANN, 2001; 2002).

The GPX enzyme (Fig. 4A) presented increase around three times greater than the control in the $48 \mathrm{HAI}$ time with the SA and fungicide treatments, as well as in the $96 \mathrm{HAI}$ time with the ASM. On the other hand, the GTS enzyme (Fig. 4B) presented values expressive in the time $120 \mathrm{HAI}$ with the ASM, whereas in the $144 \mathrm{HAI}$ time, the controls reached values statistically equal to the SA, ASM and fungicide treatments.

Glutathione GPX, GR and GST enzymes participate in the antioxidant processes, minimizing the effects of $\mathrm{H}_{2} \mathrm{O}_{2}$ (ANDERSON; DAVIS, 2004; NOCTOR et al., 2015). Therefore, they are able to reduce the plant stress when infected by the pathogen, thus contributing to its development.

KUMAR et al. (2015) evaluated the activity of some enzymes in barley after inoculation with B. sorokiniana and subsequent application of a systemic fungicide Triciclazol, from the triazol group, melanin inhibitor. The authors observed that the fungicide application promoted increased activity of some enzymes, such as antioxidant enzymes (SOD and CAT) and extracellular hydrolytic enzymes. WU; TIEDEMANN (2001), when evaluating the application of strobilurins in wheat, reported a delay in leaf senescence process and stimulation of the enzymes SOD and POD, delaying the production of superoxide $\left(\mathrm{O}_{2} \bullet-\right)$, protecting the plant of stress. JALEEL et al. (2010), after administration of paclobutrazol (PBZ) (triazol) to Catharanthus roseus, increased activity of APX, SOD, CAT, POD and polyphenoloxidases (PPO).

In Figure 5, the enzyme GR (Fig. 5A) is shown to exhibit 50\% increase in 96 and $120 \mathrm{HAI}$ times when ASM was applied. Regarding the APX (Fig. 5B), no differences were observed between all the treatments and times, showed small increase in activity in the 96 and $120 \mathrm{HAI}$ times and the controls reached higher values in the $144 \mathrm{HAI}$ time, because the plant responds to the attack of the pathogen, even if later. The treatments with the suspensions of endophytic fungi, in particular with 
fungus T. tomentosum, present higher values than those of the control, in the majority of analyzed times.

The ascorbate/glutathione cycle is the main removal system for ROS in chloroplasts. In this cycle enzymes, APX and GR are employed. $\mathrm{H}_{2} \mathrm{O}_{2}$ can be reduced and removed by APX through ascorbate as a reductant, forming the monodehydroescorbate radical (HABIG; JAKOBY, 1981; WU et al., 1996; RESENDE et al., 2003). GR catalyzes the reduction of oxidized glutathione (GSSG) to reduced GSH, plays an important role in the defense against oxidative stress, since it maintains the balance between GSSG and GSH levels in the cell (NOCTOR et al., 2015). GST are enzymes that catalyze the conjugation of GSH to electrophilic hydrophobic substrates, such as xenobiotics (YOSHIMURA et al., 2000; DIXON et al., 2002).

GPX acts in conjunction with reduced GSH, decomposing $\mathrm{H}_{2} \mathrm{O}_{2}$ in water, while simultaneously oxidizing GSH.
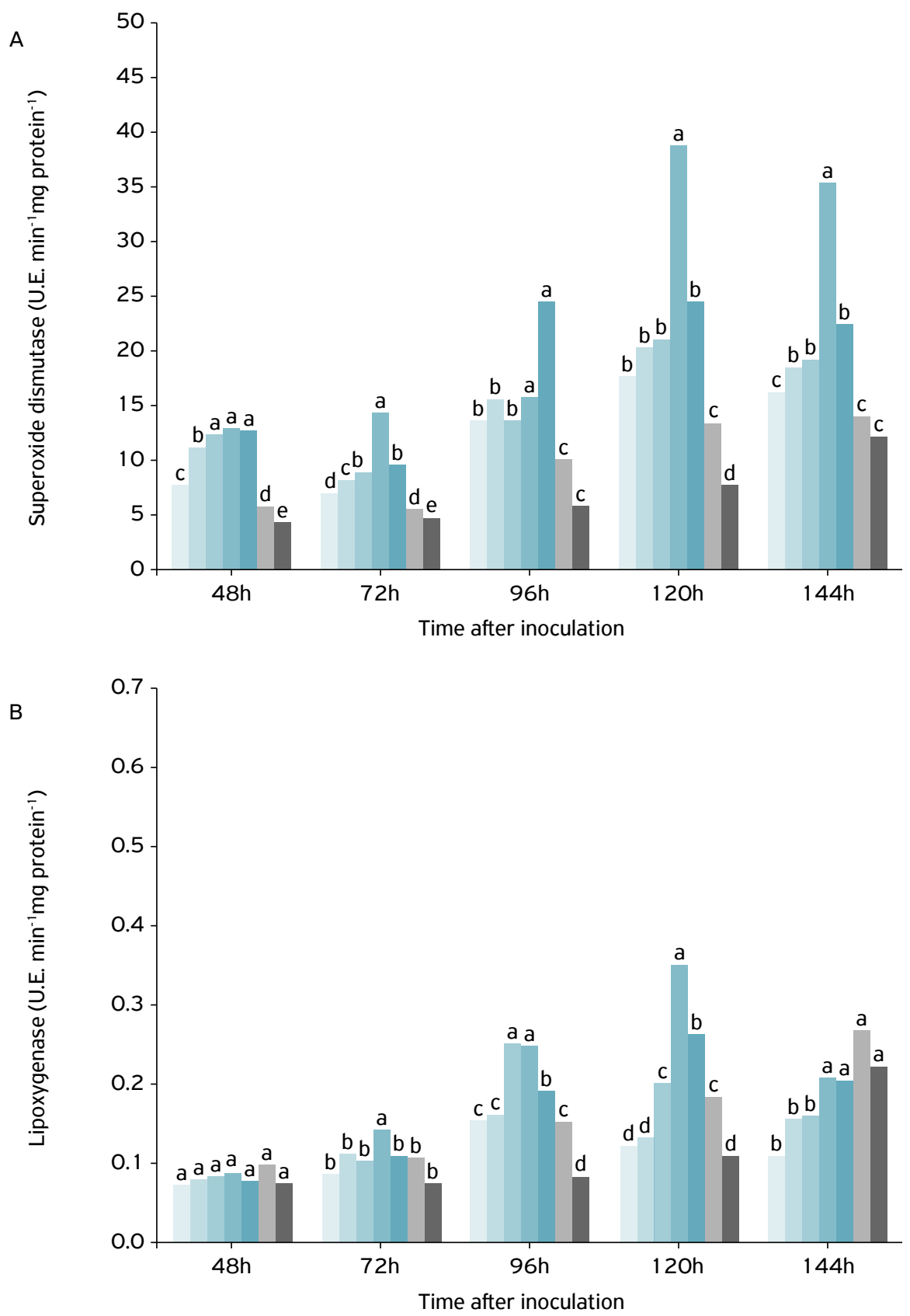

T1

T2

T3

T4

Averages followed by distinct letters between treatments differ by the Scott-Knott test at the $5 \%$ probability level; T1: suspension of Aspergillus japonicas; T2: suspension of Trichoderma tomentosum; T3: salicylic acid; T4: acibenzolar-s-methyl; T5: fungicide (Azoxystrobin with Tebuconazole); T6: application of sterile distilled water with inoculum of Bipolaris sorokiniana; T7: without any application.

Figure 3. Activity of the enzymes (A) superoxide dismutase and (B) lipoxygenase after inoculation of the Bipolaris sorokiniana pathogen. 
It is believed that endophytic fungi are capable of producing biologically active natural products (AHMAD et al., 2010; DUTTA et al., 2014). Because of this ability to reside in differentiated niches, they present a metabolic state of constant aggressiveness, thus synthesizing various metabolites. Through the production of these metabolites, endophytic fungi have the properties of activating resistance induction mechanisms in plants (GUNATILAKA, 2006; KUSARI et al.,
2009; BAE et al., 2011; HOSSEYNI-MOGHADDAM; SOLTANI, 2014).

The glutathione-ascorbate cycle can also eliminate part of $\mathrm{H}_{2} \mathrm{O}_{2}$, and involves, among others, the enzyme APX. The enzymes of this cycle are present in the chloroplasts, cytoplasm, mitochondria, peroxisomes and apoplastosis, being an increase in their activity verified in response to oxidative stress (MITTLER, 2003; RESENDE et al., 2003).
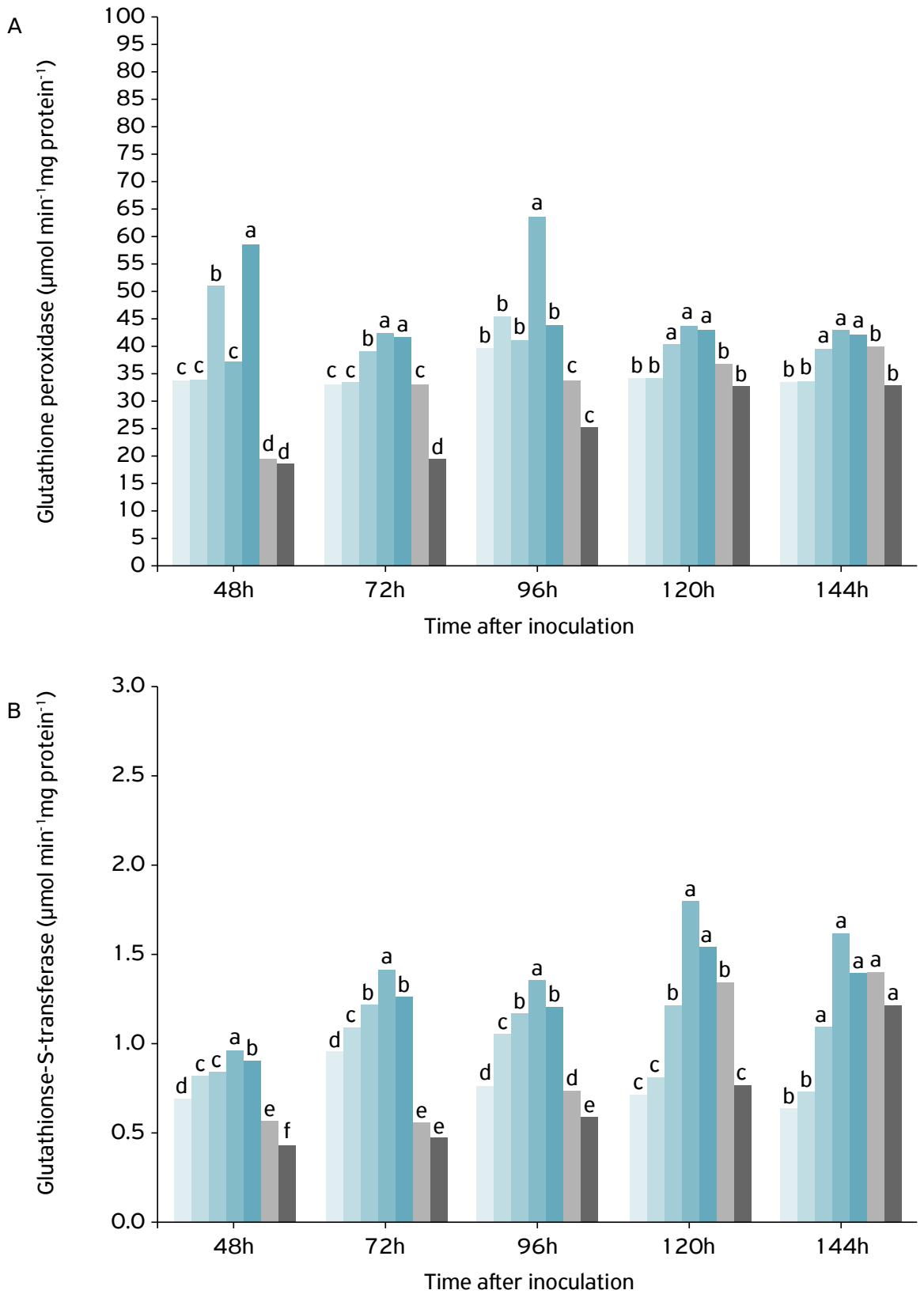

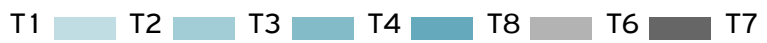

Averages followed by distinct letters between treatments differ by the Scott-Knott test at the $5 \%$ probability level; $\mathrm{T} 1$ : suspension of $A$ spergillus japonicas; T2: suspension of Trichoderma tomentosum; T3: salicylic acid; T4: acibenzolar-s-methyl; T5: fungicide (Azoxystrobin with Tebuconazole); T6: application of sterile distilled water with inoculum of Bipolaris sorokiniana; T7: without any application.

Figure 4. Activity of the enzymes $(A)$ glutathione peroxidase and $(B)$ glutathione-S-transferase, after inoculation of the Bipolaris sorokiniana pathogen. 
When applied to wheat plants, elicitor compounds were able to activate the plant protection system, reducing the effects of the pathogen and ROS. ABBASI et al. (2015) studied wheat plants that were treated with PBZ from the Triazol group and $S A$ to analyze the activity of antioxidant enzymes under dry stresses. Both PBZ and SA promoted increased activity of antioxidant enzymes. Plants treated with AS increased GPX activity (100 and 53\%), whereas PBZ minimized the negative effects of water stress, increased chlorophyll content and activity of antioxidant enzymes such as APX, CAT and GPX.

In the present study, it was verified that the antioxidant enzymes evaluated had their activities increased, especially due to the application of the fungicide treatment or ASM, but presenting promising results in relation to the evaluated fungal suspensions. Our results suggest that, in view of the application of these elicitor compounds, the plant presents
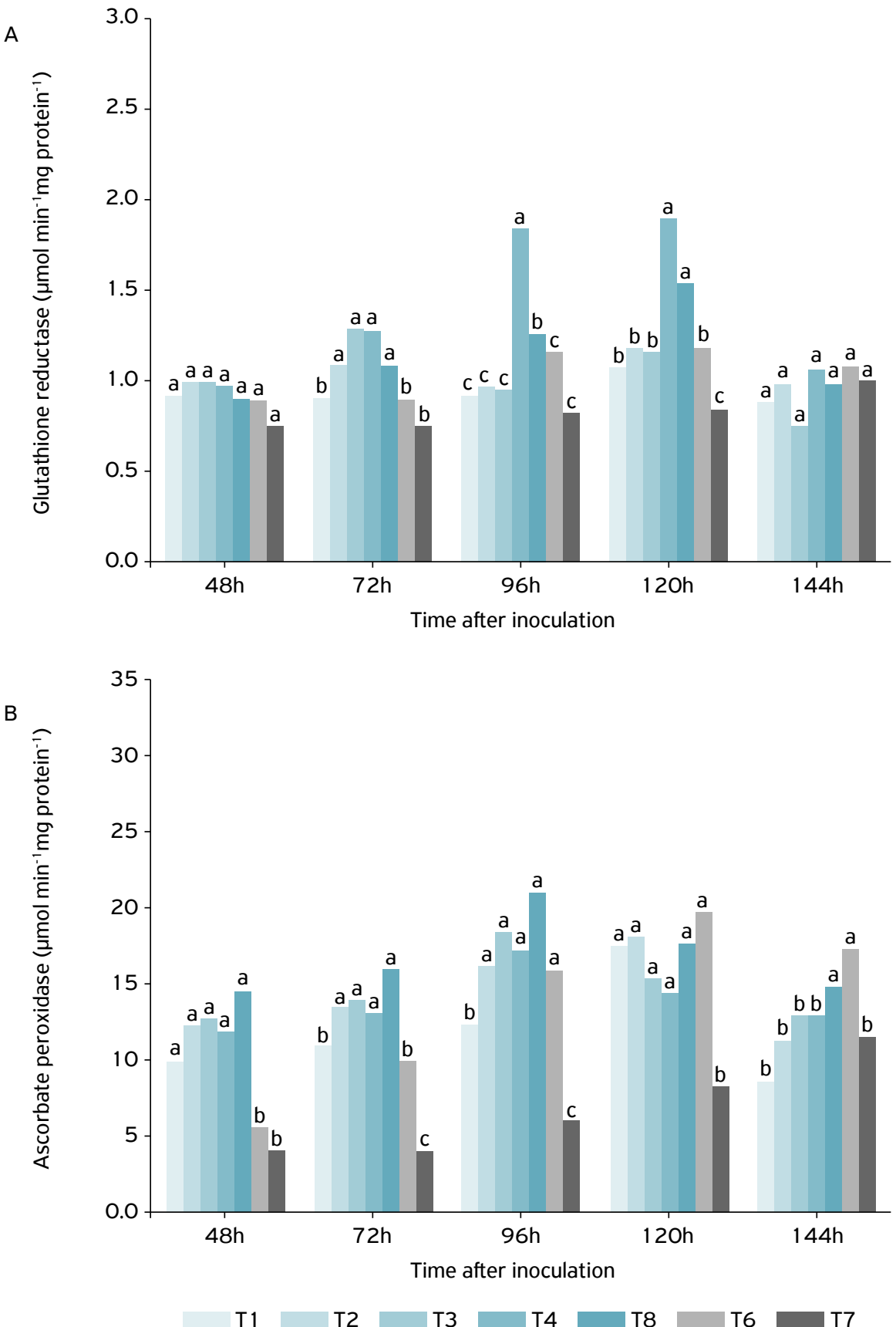

Averages followed by distinct letters between treatments differ by the Scott-Knott test at the $5 \%$ probability level; T1: suspension of Aspergillus japonicas; T2: suspension of Trichoderma tomentosum; T3: salicylic acid; T4: acibenzolar-s-methyl; T5: fungicide (Azoxystrobin with Tebuconazole); T6: application of sterile distilled water with inoculum of Bipolaris sorokiniana; T7: without any application.

Figure 5. Activity of the enzymes (A) glutathione reductase and (B) ascorbate peroxidase, after inoculation of the Bipolaris sorokiniana pathogen. 
an efficient antioxidant system in the removal of excess ROS generated during the $B$. sorokiniana infection process, which, in addition to limiting cell damage caused by the fungus, contributes to a greater resistance of the wheat against this pathogen and consequent increase of productivity. In view of the need to supply the demand for agriculture and industry in a sustainable manner through the use of eliciting biomolecules, the potential for the application of the suspensions of
T. tomentosum and A. japonicus should be better investigated, especially because of the large variety of pathogens, as well as the different responses of secondary plant metabolism to environmental adversities.

In Figure 6, the total flavonoids (Fig. 6A) had their amounts increased by approximately $50 \%$ at $72 \mathrm{HAI}$ time with the fungicide treatment and at the time $96 \mathrm{HAI}$ with ASM. MDA (Fig. 6B), a marker of lipid peroxidation, showed
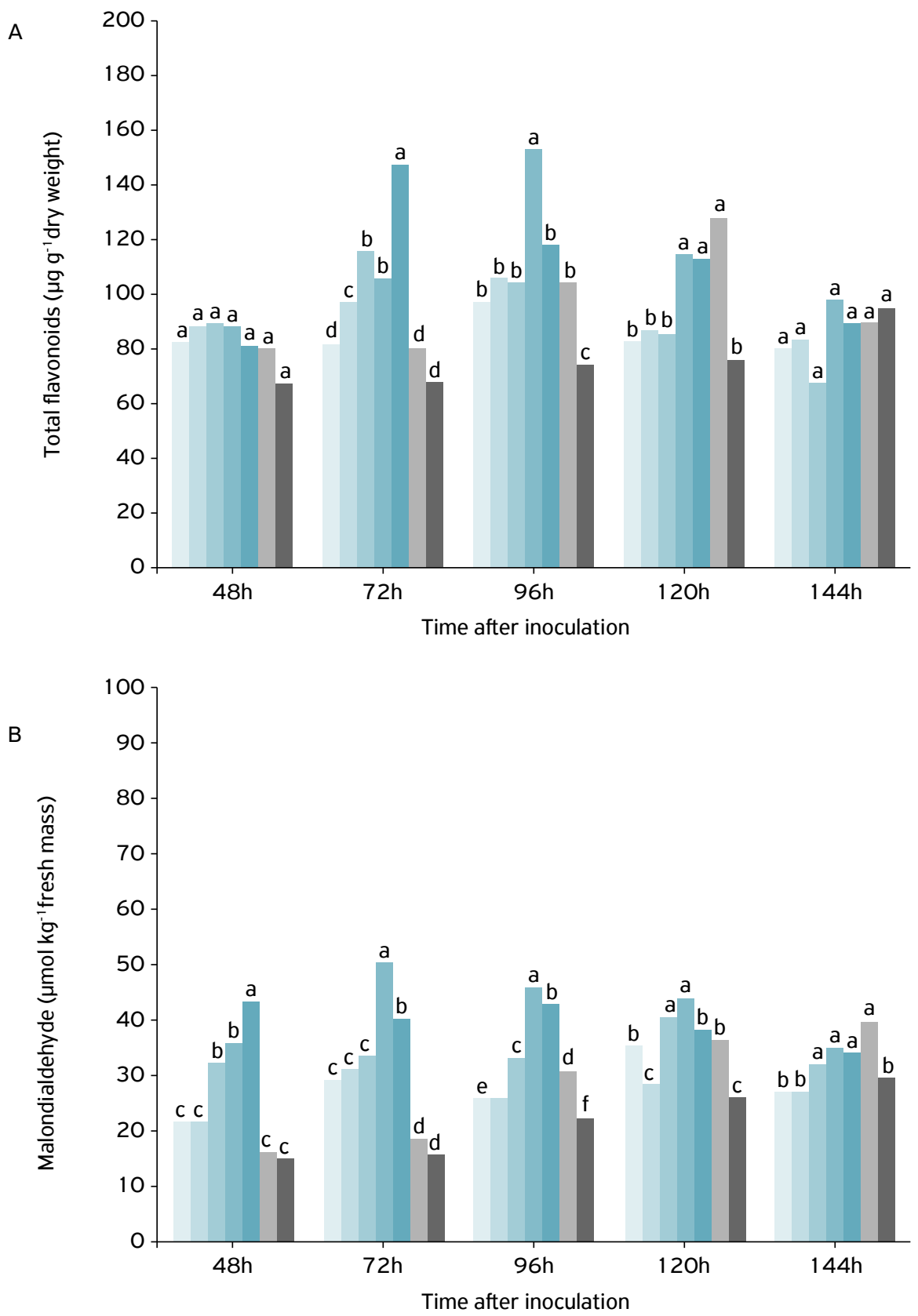

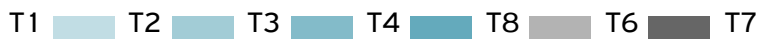

Averages followed by distinct letters between treatments differ by the Scott-Knott test at the $5 \%$ probability level; $\mathrm{T} 1$ : suspension of $A$ spergillus japonicas; T2: suspension of Trichoderma tomentosum; T3: salicylic acid; T4: acibenzolar-s-methyl; T5: fungicide (Azoxystrobin with Tebuconazole); T6: application of sterile distilled water with inoculum of Bipolaris sorokiniana; T7: without any application.

Figure 6. Amount of $(A)$ total flavonoids and $(B)$ malondialdehyde, after inoculation of the Bipolaris sorokiniana pathogen. 
expressive increase in time $48 \mathrm{HAI}$ with fungicide treatment and in $72 \mathrm{HAI}$ with ASM. In relation to both flavonoids and MDA, the values of the controls increased considerably in the 144 HAI time, being statistically equal to some treatments. The results observed for the treatments with the suspensions of endophytic fungi present higher values than those of the control in most of the times analyzed. Flavonoids, in addition to acting as antioxidant compounds, also act as antimicrobials (phytoalexins). In this way, its increase in the plant is able to minimize the effects of pathogens (AHUJA et al., 2012).

The fact that an increase of the lipid peroxidation occurs in the first HAI of the pathogen shows a common fact that the elicitor compounds promote in the plants, since they activate the ROS, and these, consequently, promote the lipid peroxidation. After applying an elicitor or the pathogen contact with the plant, with this increase of ROS, hydrogen peroxide $\left(\mathrm{H}_{2} \mathrm{O}_{2}\right)$ exerts, for example, a toxic effect on the pathogen and as a signal for the hypersensitivity reaction (HR) activating ROS (RESENDE et al., 2003). Therefore, the production of MDA is an indication that the plant is undergoing oxidative stress, producing $\mathrm{H}_{2} \mathrm{O}_{2}$ and, consequently, the antioxidant enzymes convert $\mathrm{H}_{2} \mathrm{O}_{2}$ into substances not harmful to the plant. $\mathrm{H}_{2} \mathrm{O}_{2}$ is part of the oxidative stress, but, also, it fights the pathogen directly and indirectly the activation of the defense system.

ALDESUQUY; GHANEM (2015) after applying SA in wheat under water stress, it was found that it increased the activity of the PPO, POD and phenylalanine ammon iolase (PAL) enzymes, also observing increase in the content of anthocyanin, lycopene and $\beta$-carotene content.

After application of SA in wheat infected with Mycosphaerella graminicola, they showed increase in the activity of the CAT,
POX and PPO enzymes, which could be explained as a process of oxidation of phenolic compounds, which may limit the fungal growth (GHOLAMNEZHAD et al., 2016), SAHU; SABAT (2011), after applying the AS in wheat plants, found increased roots, increased SOD and MDA activity, whereas the CAT, POX and APX enzymes showed no significant changes.

HASSANEIN et al. (2016), after applying the filtrate of the Fusarium fungus to $20 \%$ in seedlings of three wheat cultivars, found significant increase in the activity of antioxidant enzymes (CAT, POD and APX) as compared to those not inoculated. In addition, the content of proline, total phenols and flavonoids also increased. KHAN et al. (2013), after applying the combined endophytic fungus to SA in peppers, found increase in the activity of the CAT, POX and PPO enzymes.

\section{CONCLUSION}

When evaluating the antioxidant response in wheat plants against the B. sorokiniana pathogen, the best results were evidenced by the application of ASM or fungicide. However, it was found that both fungi suspensions evaluated, as well as SA, also had the potential to activate these mechanisms. In particular, the suspensions of endophytic fungi $A$. japonicus and T. tomentosum were promising as brown spot control agents, as they were able to reduce the severity of the disease, as well as to provide significant increase in antioxidant enzymes, total flavonoids and MDA. Further studies are suggested in order to better elucidate the performance of $A$. japonicus and T. tomentosum suspensions as elicitors of the wheat responses to the pathogen in question.

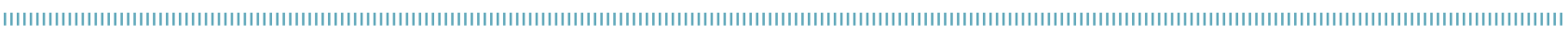
REFERENCES

\begin{abstract}
ABBASI, A.; SHEKARI, F.; MUSTAFAVI, S.H. Effect of paclobutrazol and salicylic acid on antioxidants enzyme activity in drought stress in wheat. Idesia, v.33, n.4, p.5-13, 2015. http://dx.doi. org/10.4067/SO718-34292015000400002
\end{abstract}

AHMAD, P.; JALEEL, C.A.; SALEM, M.A.; NABI, G.; SHARMA, S. Roles of Enzymatic and non-enzymatic antioxidants in plants during abiotic stress. Critical Reviews in Biotechnology, v.30, n.3, p.161175, 2010. http://dx.doi.org/10.3109/07388550903524243

AHUJA, I.; KISSEN, R.; BONES, A.M. Phytoalexins in defense against pathogens. Trends in Plant Science, v.17, n.2. p.73-90, 2012. https://doi.org/10.1016/j.tplants.2011.11.002

ALDESUQUY, H.; GHANEM, H. Exogenous salicylic acid and trehalose ameliorate short term drought stress in wheat cultivars by up-regulating membrane characteristics and antioxidant defense system. Journal of Horticulture, v.2, n.2, p.1-10, 2015. https://doi.org/10.4172/2376-0354.1000139

ANDERSON, J.V.; DAVIS, D.G. Abiotic stress alters transcript profiles and activity of glutathione S-transferase, glutathione peroxidase, and glutathione redutase in Euphorbia esula. Physiologia Plantarum, v.120, n.3, p.421-433, 2004. 10.1111/j.0031-9317.2004.00249.x

ANTONIAZZI, N.; DESCHAMPS, C. Controle de Bipolaris sorokiniana e rendimento de grãos em cevada e rendimento de grãos em cevada após aplicação de elicitores e fungicida após aplicação de elicitores e fungicida. Acta Scientiarum. Agronomy, Maringá, v.29, supl. spe., p.695-700, 2007. http://dx.doi.org/10.4025/ actasciagron.v29i5.749 
ARAÚJO, W.L.; LIMA, A.O.S.; AZEVEDO, J.L.; MARCON, J.; KUKLINSKY-SOBRAL, J.; LACAVA, P.T. Manual: isolamento de microrganismos endofíticos. Piracicaba: Centro Acadêmico Luiz de Queiroz, 2002. 86p.

AXELROD, B.; CHEESEBROUGH, T.M.; LAASKO, S. Lipoxygenases from soybeans. Methods in Enzymology, v.71, p.441-451, 1981. doi:10.1016/0076-6879(81)71055-3

BAE, H.; ROBERTS, D.P.; LIM, H.S.; STREM, M.; PARK, S.C.; RYU, C.M. MELNICK, R.L.; BAILEY, B.A. Endophytic Trichoderma isolates from tropical environments delay disease onset and induce resistance against phytophthora capsici in hot pepp.er using multiple mechanisms. Molecular Plant-Microbe Interactions, v.24, n.3, p.336-351, 2011 . http://dx.doi. org/10.1094/MPMI-09-10-0221

BHATTACHARJEE, S. Sites of generation and physicochemical basis of formation of reactive oxygen species in plant cell. In: GUPTA, S.D. Reactive oxygen species and antioxidants in higher plants. Enfield: Science Publishers, 2010. p.1-30.

BRADFORD, M.M.A rapid and sensitive method for the quantitation of microgram quantities of protein utilizing the principle of proteindye binding. Analytical Biochemistry, v.72, n.1-2, p.248-254, 1976. https://doi.org/10.1016/0003-2697(76)90527-3

BUEGE, J.A.; AUST, S.D. Microsomal lipid peroxidation. Methods in Enzymology, v.52, p.302-310, 1978. https://doi.org/10.1016/ S0076-6879(78)52032-6

CAMPBELL, C.L.; MADDEN, L.V. (eds.). Introduction to plant disease epidemiology. New York, NY: John Wiley \& Sons, 1990. 532p.

CARVALHO, D.D.C.; GERALDINE, A.M.; LOBO JUNIOR, M.; MELLO, S.C.M. Biological control of white mold by Trichoderma harzianum in common bean under field conditions. Pesq. agropec. bras., Brasília, v.50, n.12, p.1220-1224, dez. 2015. http://dx.doi.org/10.1590/ so $100-204 \times 2015001200012$

CATANEO, A.C.; DÉSTRO, G.F.G.; FERREIRA, L.C.; CHAMMA, K.L.; SOUZA, D.C.F. Glutathione -transferase activity on the degradation of the herbicide glyphosate in maize (Zea mays) plants. Planta Daninha, Rio de Janeiro, v.21, n.2, p.307-312, 2003.

CHANG, C.C.; YANG, M.H.; WEN, H.M.; CHERN, J.C. Estimation of total flavonoid content in propolis by two complementary colorimetric methods. Journal of Food and Drug Analysis, v. 10, n.3, p. 178-182, 2002.

CORDO, C.; MONACO, C.I.; SEGARRA, C.I.; SIMON, M.R.; MANSILLA, A.Y.; PERELLÓ, A.E.; KRIPELZ, N.I.; BAYO, D.; CONDE, R.D. Trichoderma spp. as elicitor of wheat plant defense responses against
Septoria tritici. Biocontrol Science and Technology, v. 17, n.7, p.687698, 2007. https://doi.org/10.1080/09583150701527094

DEBONA, D.; RODRIGUES, F.Á.; RIOS, J.A.; NASCIMENTO, K.J.T. Biochemical changes in the leaves of wheat plants infected by Pyricularia oryzae. Phytopathology, v.102, n.12, p.1121-1129, 2012. https://doi.org/10.1094/PHYTO-06-12-0125-R

DIXON, D.P.; LAPTHORN, A.; EDWARDS, R. Plant glutathione transferases. Genome Biology, v.3, p.1-10, 2002. https://doi. org/10.1186/gb-2002-3-3-reviews3004

DUTTA, D.; PUZARI, K.C.; GOGOI, R.; DUTTA, P. Endophytes: exploitation as a tool in plant protection. Brazilian Archives of Biology and Technology, v.57 n.5, p.621-629, 2014. http:// dx.doi.org/10.1590/S1516-8913201402043

DUVEILLER, E.; CHAND, R.; SINGH, H.V.; JOSHI, A.K. Physiological and Morphological aspects of Bipolaris sorokiniana conidia surviving on wheat straw. The Plant Pathology Journal, v.18, n.6, p.328332, 2002. http://dx.doi.org/10.5423/PPJ.2002.18.6.328

EMPRESA BRASILEIRA DEPESQUISA AGROPECUÁRIA (EMBRAPA). Comissão Sul-Brasileira de Pesquisa de Trigo. In: REUNIÃO DA COMISSÃO SUL-BRASILEIRA DE PESQUISA DE TRIGO, 36., 2004, Passo Fundo. Indicações técnicas da Comissão Sul-Brasileira de Pesquisa de Trigo: trigo e triticale - 2004. Passo Fundo: Comissão Sul-Brasileira de Pesquisa de Trigo, 2004. 152 p.

EMPRESA BRASILEIRA DEPESQUISA AGROPECUÁRIA (EMBRAPA). Sistema Brasileiro de Classificação de Solos. 3. ed. Rio de Janeiro: Embrapa Solos, 2013. 353p.

FERREIRA, R.R.; FORNAZIER, R.F.; VITÓRIA, A.P.; LEA, P.J.; AZEVEDO, R.A. Changes in antioxidant enzyme activities in soybean under cadmium stress. Journal of Plant Nutrition, New York, v.25, n.2, p.327-342, 2006. https://doi.org/10.1081/ PLN-100108839

FLORES, A.V.; BORGES, E.E.L.; GUIMARÃES, V.M.; GONÇALVES, J.F.C.; ATAÍDE, G.M.; BARROS, D.P. Atividade enzimática durante a germinação de sementes de Melanoxylon brauna Schott sob diferentes temperaturas. Cerne, v.20, n.3, p.401-408, 2014. http://dx.doi.org/10.1590/01047760201420031399

GAJERA, H.; DOMADIYA, R.; PATEL, S.; KAPOPARA, M.; GOLAKIYA, B. Molecular mechanism of Trichoderma as bio-control agents against phytopathogen system - a review. Current Research in Microbiology and Biotechnology, v.1, n.4, p.133-142, 2013.

GAO, Q.M.; ZHU, S.; KACHROO, P.; KACHROO, A. Signal regulators of systemic acquired resistance. Frontiers in Plant Science, v.6, p.228, 2015. http://dx.doi.org/10.3389/fpls.2015.00228 
GHOLAMNEZHAD, J.; SANJARIAN, F.; GOLTAPEH, E.M.; SAFAIE, N.; RAZAVI, K. Effect of salicylic acid on enzyme activity in wheat in immediate early time after infection with Mycosphaerella graminicola. Scientia Agriculturae Bohemica, v.47, n.1, p.1-8, 2016. http://dx.doi.org/10.1515/sab-2016-0001

GIANNOPOLITIS, C.N.; REIS, S.K. Superoxide dismutase I. Occurrence in higher plants. Plant Physiology, v.59, n.2, p.309-314, 1977.

GILL, S.S.; NASER, A.A.; GILL, R.; YADAV, S.; HASANUZZAMAN, M.; FUJITA, M.; PANCHANAND, S.C.; TUTEJA, N. Superoxide dismutase - mentor of abiotic stress tolerance in crop plants Sarvajeet Singh. Environmental Science and Pollution Research, v.22, p.1037510394, 2015. https://doi.org/10.1007/s1 1356-015-4532-5

GUNATILAKA, A.A.L. Natural products from plant associated microorganisms: distribution, structural diversity, bioactivity, and implications of their occurrence. Journal of Natural Products, v.69, n.3, p.509-526, 2006. https://doi.org/10.1021/np058128n

GUZZO, S.D.; MARTINS, E.M.F. Local and systemic induction of $\beta$-1,3-glucanase and chitinase in coffee leaves protected against Hemileia vastatrix by Bacillus thuringiensis. Journal of Phytopathology, v.144, n.9-10, p.449-454, 1996. https://doi. org/10.1111/j.1439-0434.1996.tb00322.x

HABIG, W.H.; JAKOBY, W.B. Assays for determination of glutathione S-transferase. Methods in Enzymology, New York, v.77, p.398-405, 1981. https://doi.org/10.1016/S0076-6879(81)77053-8

HASAN, M.M.; RAHMAN, S.M.E.; KIM, G.H.; APDALLAH, E.; $\mathrm{OH}, \mathrm{D} . \mathrm{H}$. Antagonistic potentiality of Trichoderma harzianum towards seed-borne fungal pathogens of winter wheat cv. Protiva in vitro and in vivo. Journal Microbiology Biotechnology, v.22, n.5, p.585-591, 2012.

HASAN, M.M.; RAHMAN, S.M.E.; KIM, G.H.; APDALLAH, E.; OH, D.H. Biological control of wheat diseases caused by Bipolaris sorokiniana, Fusarium graminearum and Aspergillus flavus with antagonist's of Trichoderma spp. Persian Gulf Crop Protection, v.2, n.3, p. 1-9, 2013.

HASSANEIN, R.A.; HASHEM, H.A.; FAHMY, A.H.; IBRAHIM, A.S.; SHIHY, O.M.; QAID, EL E.A. Protection against fusarium head blight: important defense mechanisms studied in three regenerated Egyptian wheat cultivars. Journal of Stress Physiology () Biochemistry, v.12, n.2, p.18-43, 2016.

HAYAT, Q.; HAYAT, S.; IRFAN, M.; AHMAD, A. Effect of exogenous salicylic acid under changing environment: a review. Environmental and Experimental Botany, v.68, n. 1, p.14-25, 2010. https://doi. org/10.1016/j.envexpbot.2009.08.005
HORVÁTH, E.; JANDA, T.; SZALAI, G.; PÁLDI, E. In vitro salicylic acid inhibition of catalase activity in maize: differences between the isoenzymes and a possible role in the induction of chilling tolerance. Plant Science, v.163, n.6, p.1 129-1 135, 2002. https:// doi.org/10.1016/SO168-9452(02)00324-2

HOSSAIN, M.M.; HOSSAIN, I.; KHALEQUZZAMAN, K.M. Biological control of leaf blight of wheat caused by Bipolaris sorokiniana. Bulletin Institute Tropical Agriculture, Kyushu University, v.39, n. 1, p.43-51, 2016. https://doi.org/10.11189/bita.39.043

HOSSEYNI-MOGHADDAM, M.S.; SOLTANI, J. Bioactivity of endophytic Trichoderma fungal species from the plant family Cupressaceae. Annals of Microbiology, v.64, n.2, p.753-761, 2014. https://doi.org/10.1007/s13213-013-0710-1

HUSEYNOVA, I.M.; ALIYEVA, D.R.; ALIYEV, J.A. Subcellular localization and responses of superoxide dismutase isoforms in local wheat varieties subjected to continuous soil drought. Plant Physiology and Biochemistry, v.81, p.54-60, 2014. https://doi. org/10.1016/j.plaphy.2014.01.018

IFTIKHAR, S.; ASAD, S.; RATTU, A.U.R; MUNIR, A.; FAYYAZ, M. Screening of commercial wheat varieties to spot blotch under controlled and field conditions. Pakistan Journal of Botany, v.44, n. 1, p.361-363, 2012.

INBAR, M.; DOOSTDAR, H. GERLING, D.; MAYER, R.T. Induction of systemic acquired resistance in cotton by BTH has a negligible effect on phytophagous insects. Entomologia Experimentalis et Applicata, Amsterdam, v.99, n.1, p.65-70, 2001. https://doi. org/10.1023/A:1018952329549

INSTITUO AGRONÔMICO DO PARANÁ(IAPAR). Sugestão de adubação e calagem para culturas de interesse econômico no Estado do Paraná. Londrina: IAPAR, 2003. 30 p. (Coord. Edson Lima de Oliveira).

JALEEL, C.A.; SALEM, M.A.; HASANUZZAMAN, M.; NAHAR, K. Plant growth regulator interactions results enhancement of antioxidant enzymes in Catharanthus roseus Cheruth. Journal of Plant Interactions, v.5, n.2, p.135-145, 2010. https://doi. org/10.1080/17429140903377456

JAMES, W.C. An illustrated series of assessment keys for plant diseases, their preparation, and usage. Canadian Plant Diseases Survey, v.51, p.39-45, 1971.

KHAN, A.L.; WAQAS, M.; HAMAYUN, M.; AL-HARRASI, A.; AL-RAWAHI, A.; LEE, I. Co-synergism of endophyte Penicillium resedanum LK6 with salicylic acid helped Capsicum annuum in biomass recovery and osmotic stress mitigation. BioMed Central Microbiology, v.13, n.51, p.1-13, 2013. https://doi. org/10.1186/1471-2180-13-51 
KIM, Y.H.; KWAK, S.S. The role of antioxidant enzymes during leaf development. In: GUPTA, S.D. Reactive oxygen species and antioxidants in higher plants. Enfield: Science Publishers, 2010. p.129-150.

KONG, L.; WANG, F.; SI, J.; FENG, B.; ZHANG, B.; LI, S.; WANG, Z. Increasing in ROS levels and callose deposition in peduncle vascular bundles of wheat (Triticum aestivum L.) grown under nitrogen deficiency. Journal of Plant Interactions, v.8, n.2, p.109-116, 2013. https://doi.org/10.1080/17429145.2012.712723

KRUPA E SILVA, P. Biorreguladores aplicados em diferentes estádios fenológicos do trigo e seu efeito no desenvolvimento da planta ena qualidade da farinha. 2014. 73p. Dissertation (Mestrado em Agronomia) Universidade Estadual do Centro-Oeste, Guarapuava, 2014.

KUMAR, M.; CHAND, R.; DUBEY, R.S.; SHAH, K. Effect of Tricyclazole on morphology, virulence and enzymatic alterations in pathogenic fungi Bipolaris sorokiniana for management of spot blotch disease in barley. World Journal of Microbiology and Biotechnology, v.3 1, n. 1 , p.23-35, 2015. https://doi.org/10.1007/s1 1274-014-1756-3

KUSARI, S.; LAMSHÖFT, M.; SPITELLER, M. Aspergillus fumigatus Fresenius, an endophytic fungus from Juniperus communis L. Horstmann as a novel source of the anticancer pro-drug deoxypodophyllotoxin. Journal of Applied Microbiology, v.107, n.3, p.1019-1030, 2009. https://doi. org/10.1111/j.1365-2672.2009.04285.x

MINOTTO, E.; MANN, M.B.; VÉLEZ-MARTIN, E.; FELTRIN, T.; MILAGRE, L.P.; SPADARI, C.; VAN DER SAND, S.T. Pathogenicity of monosporic and polysporin Bipolaris sorokiniana isolates to wheat seed seedling inder condition. African Journal of Microbiology Research, v.8, n.28, p.2697-2704, 2014.

MISHRA, A.K.; RAI, R.; AGRAWAL, S.B. Individual and interactive effects of elevated carbon dioxide and ozone on tropical wheat (Triticum aestivum L.) cultivars with special emphasis on ROS generation and activation of antioxidant defense system. Indian Journal of Biochemistry and Biophyicss, v.50, n.2, p.139-149, 2013.

MITTLER, R. Oxidative stress, antioxidants and stress tolerance. Trends in Plant Science, v.7, n.9, p.405-410, 2002. https://doi. org/10.1016/S1360-1385(02)02312-9

MOORE, J.; LIU, J.G.; ZHOU, K.; YU, L. Effects of genotype and environment on the antioxidant properties of hard winter wheat bran. Journal of Agricultural and Food Chemistry, v.54, n. 15, p.5315322, 2006. https://pubs.acs.org/doi/abs/10.1021/jf060381I

NAGALAKSHMI, N.; PRASAD, M.N.V. Responses of glutathione cycle enzymes and glutathione metabolism to copper stress in
Scenedesmus bijugatus. Plant Science, v.160, n.2, p.291-299, 2001. https://doi.org/10.1016/S0168-9452(00)00392-7

NAKANO, Y.; ASADA, K. Hydrogen peroxide is scavenged by ascorbate specific peroxidase in spinach chloroplasts. Plant and Cell Physiology, Tokyo, v.22, n.5, p.867-880, 1981. https://doi. org/10.1093/oxfordjournals.pcp.a076232

NOCTOR, G.; LELARGE-TROUVERIE, C.; MHAMDI, A. The metabolomics of oxidative stress. Phytochemistry, v. 112 , p.3353, 2015. https://doi.org/10.1016/j.phytochem.2014.09.002

OLIVEIRA, M.D.M.; VARANDA, C.M.R.; FÉLIX, M.R.F. Induced resistance during the interaction pathogen $x$ plant and the use of resistance inducers. Phytochemistry Letters, v.15, p.152158, 2016. https://doi.org/10.1016/j.phytol.2015.12.011

OLIW, E.H. Plant and fungal lipoxygenases. Prostaglandins $\diamond$ Other Lipid Mediators, v.68-69, p.313-323, 2002.

PEREIRA, J.O.; AZEVEDO, J.L.; PETRINI, O. Endophytic fungi of Stylosanthes: a first report. Mycologia, v.85, n.3, p.362-364, 1993. https://doi.org/10.2307/3760696

PERELLÓ, A.E.; MONACO, C.I.; SIMON, M.R.; SISTERNA, M.; DALBELLO, G. Biocontrol efficacy of Trichoderma isolates for tan spot of wheat in Argentina. Crop Protection, v.22, n.9, p.1099-1 106, 2003. https://doi.org/10.1016/SO261-2194(03)00143-1

PERELLÓ, A.E.; MONACO, C.I.; MORENO, M.V.; CORDO, C.A.; SIMON, M.R. The effect of Trichoderma harzianum and $T$. koningii on the control of tan spot (Pyrenophora tritici-repentis) and leaf blotch (Mycosphaerella graminicola) of wheat under field conditions in Argentina. Journal Biocontrol Science and Technology, v.16, n.8, p.803-813, 2006. https://doi. org/10.1080/09583150600700099

PERELLÓ, A.E.; MORENO, M.V.; MONACO, C.I.; CORDO, C.A.; SIMON, M.R. Effect of Trichoderma spp. isolates for biological control of tan spot of wheat caused by Pyrenophora tritici-repentis under field conditions in Argentina. BioControl, v.53, p.895-904, 2008.

RAO, A.; AHMAD, S.D.; SABIR, S.M.; AWAN, S.I.; SHAH, A.H.; ABBAS, S.R.; SHAFIQUE, S.; KHAN, F.; CHAUDHARY, A. Potential antioxidant activities improve salt tolerance in ten varieties of wheat (Triticum aestivum L.). American Journal of Plant Sciences, v.4, n.6A, p.69-76, 2013. https://doi.org/10.4236/ ajps.2013.46A010

RESENDE, M.L.V.; SALGADO, S.M.L.; CHAVES, Z.M. Espécies ativas de oxigênio na resposta de defesa de plantas a patógenos. Fitopatologia Brasileira, v.28, n.2, p.123-130, 2003. http:// dx.doi.org/10.1590/SO100-41582003000200001 
RIOS, J.A.; RODRIGUES, F.A.; DEBONA, D.; RESENDE, R.S.; MOREIRA, W.R.; ANDRADE, C.C.L. Induction of resistance to Pyricularia oryzae in wheat by acibenzolar-S-methyl, ethylene and jasmonic acid. Tropical Plant Pathology, v.39, n.3, p.224-233, 2014. http:// dx.doi.org/10.1590/S1982-56762014000300006

SAHU, G.K.; SABAT, S.C. Changes in growth, pigment content and antioxidants in the root and leaf tissues of wheat plants under the influence of exogenous salicylic acid. Brazilian Journal of Plant Physiology, v.23, n.3, p.209-1 18, 2011 . http://dx.doi. org/10.1590/S1677-04202011000300005

SCANDALIOS, J.G.; ACEVEDO, A.; RUZSA, S. Catalase gene expression in response to chronic high temperature stress in maize. Plant Science, v. 156, p. 103-110, 2000.

SERKEDJIEVA, J. Antioxidant effects of plant polyphenols: a case study of a polyphenol-rich extract from Geranium sanguineum $L$. In: GUPTA, S.D. Reactive oxygen species and antioxidants in higher plants. Enfield: Science Publishers, 201 1. p.275-293.

SORAHINOBAR, M.; NIKNAM, V.; EBRAHIMZADEH, H.; SOLTANLOO, H.; BEHMANESH, M.; ENFERADI, S.T. Central role of salicylic acid in resistance of wheat against Fusarium graminearum. Journal of Plant Growth Regulation, v.35, n.2, p.477-491, 2016. http:// dx.doi.org/10.1007/s00344-015-9554-1

TALAAT, N.B.; SHAWKY, B.T. Modulation of the ROS scavenging system in salt-stressed wheat plants inoculated with arbuscular mycorrhizal fungi. Journal of Plant Nutrition and Soil Science, v.177, n.2, p.199-207, 2014. http://dx.doi.org/10.1002/ jpln.201200618

THAKUR, M.; SOHAL, B.S. Role of elicitors in inducing resistance in plants against pathogen infection: a review. ISRN Biochemistry, v.2013, p.1-10, 2013. http://dx.doi. org/10.1155/2013/762412

VARGA, B.; JANDA, T.; LÁSZLÓ, E.; VEISZ, O. Influence of abiotic stresses on the antioxidant enzyme activity of cereals. Acta Physiologiae Plantarum, v.34, n.3, p.49-858, 2012. https:// doi.org/10.1007/s1 1738-011-0882-x

WAGHUNDE, R.R.; SHELAKE, R.M.; SABALPARAA, N. Trichoderma: a significant fungus for agriculture and environment. African
Journal of Agricultural Research, v.11, n.22, p.1952-1965, 2016. https://doi.org/10.5897/AJAR2015.10584

WREGE, M.S.; STEINMETZ, S.; REISSER JUNIOR, C.; ALMEIDA, I.R. (ed.). Atlas climático da Região Sul do Brasil: Estados do Paraná, Santa Catarina e Rio Grande do Sul. Pelotas: Embrapa Clima Temperado; Colombo: Embrapa Florestas, 2011 . 333p.

WU, J.; OMOKAWA, H.; HATZIOS, K.K. Glutathione S-transferase activity in unsafened and fenclorim-safened rice (Oryza sativa). Pesticide Biochemistry and Physiology, New York, v.54, n.3, p.220-229, 1996. https://doi.org/10.1006/pest. 1996.0026

WU, Y.X.; VON TIEDEMANN, A. Physiological effects of azoxystrobin and epoxiconazole on senescence and the oxidative status of wheat. Pesticide Biochemistry and Physiology, v.71, n. 1, p. 1-10, 2001. https://doi.org/10.1006/pest.2001.2561

WU, Y.X.; VON TIEDEMANN, A. Impact of fungicides on active oxygen species and antioxidant enzymes in spring barley (Hordeum vulgare L.) exposed to ozone. Environmental Pollution, v. 1 16, n. 1, p.37-47, 2002.

YOSHIMURA, K.; YABUTA, Y.; ISHIKAWA, T.; SHIGEOKA, S. Expression of spinach ascorbate peroxidase isoenzymes in response to oxidative stresses. Plant Physiology, v.123, n.1, p.223-233. 2000. https://doi.org/10.1 104/pp.123.1.223

YOSHIOKA, Y.; ICHIKAWA, H.; NAZNIN, H.A.; KOGURE, A.; HYAKUMACHI, M. Systemic resistance induced in Arabidopsis thaliana by Trichoderma asperellum SKT-1, a microbial pesticide of seed-borne diseases of rice. Pest Management Science, v.68, n. 1, p.60-66, 2012. https://doi.org/10.1002/ps.2220

ZHANG, Y.J.; ZHANG, X.; CHEN, C.J.; ZHOU, M.G.; WANG, H.C. Effects of fungicides JS399-19, azoxystrobin, tebuconazloe, and carbendazim on the physiological and biochemical indices and grain yield of winter wheat. Pesticide Biochemistry and Physiology, v.98, n.2, p. 151-157, 2010. https://doi.org/10.1016/j. pestbp.2010.04.007

ZHAO, J.; SHAN, T.; MOU, Y.; ZHOU, L. Plant-derived bioactive compounds produced by endophytic fungi. Mini-Reviews in Medicinal Chemistry, v. 11 , p 159-168, 2011 . https://doi. org/10.2174/138955711794519492 